
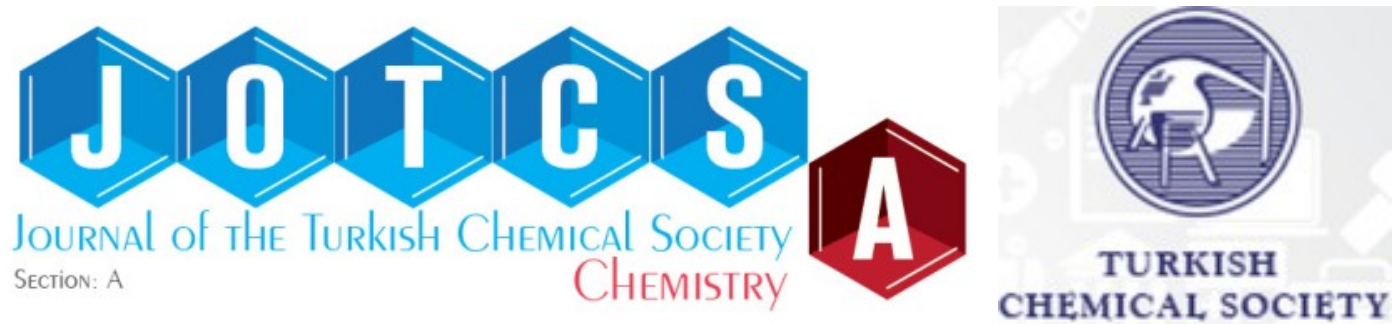

\title{
GAMMA DOSE VALUES OF STRATIGRAPHIC UNITS OF BEHRAMKALE (ÇANAKKALE) - ZEYTİNLİ (EDREMİT-BALIKESİR) SECTION OF KAZ MOUNTAINS
}

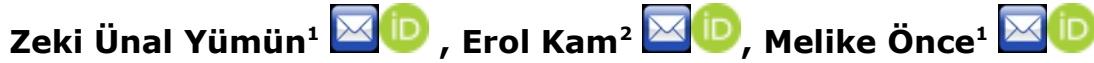 \\ ${ }^{1}$ Tekirdağ Namık Kemal University, Tekirdağ \\ ${ }^{2}$ Yıldız Technical University, Istanbul
}

\begin{abstract}
In this study, gamma dose values were measured at 25 locations around a distance of $60 \mathrm{~km}$ parallel to the Aegean Sea in Güre, Küçükkuyu and Kazdağı regions. These measurements were made by keeping the Eberline Smart Portable (ESP) scintillator detector constant at a height of 1 meter above ground level. A SPA- 6 plastic scintillation sensor is connected to the instrument tip to perform the measurement. These devices are direct measurement of external radiation. As the measurements were carried out in the open area, 0.2 occupancy factor was used in the calculations. In the studies, the highest effective dose value was calculated as $0.3 \mathrm{mSv}$ at the location 2 (Asos Kadırga Bay). The lowest effective dose value is $0.054 \mathrm{mSV}$ at the 15 th location (Avcilar Village Mountain slope) and the average annual gamma dose is $0.14 \mathrm{mSv}$. For the study area, when the lifetime risk of cancer was calculated using gamma effective dose values, it was determined at the highest 2 . locations $(0.0012)$ and the lowest at the 15 th locations $\left(0,21 \times 10^{-3}\right)$. The average lifetime cancer risk value $\left(2,39 \times 10^{-4}\right)$ of Turkey, were compared with values calculated in this study. In this comparison, the gamma dose values of locations 9 and 15 were lower and the values of other locations were higher.
\end{abstract}

Keywords: Gamma dose, annual effective dose, Kaz Mountains, Behramkale, Edremit Bay.

Submitted: May 14, 2019. Accepted: November 26, 2019.

Cite this: Yümün ZÜ, Kam E, Önce M. GAMMA DOSE VALUES OF STRATIGRAPHIC UNITS OF BEHRAMKALE (ÇANAKKALE) - ZEYTİNLİ (EDREMİT-BALIKESİR) SECTION OF KAZ MOUNTAINS. JOTCSA. 2020;7(1):207-14.

DOI: https://doi.org/10.18596/jotcsa.565054.

*Corresponding author. E-mail: zyumun@nku.edu.tr.

\section{INTRODUCTION}

The world is always under the influence of cosmic radiation coming from outer space. An average of $82 \%$ of the radiation dose of living organisms per year is due to natural sources (1-5). Environmental ionized background radiation levels are determined by two different sources, natural and artificial. Natural radiation sources consist of ionized particles derived from cosmic rays and radioactive isotopes originating from earth's crust. Cosmic rays produce secondary reaction products by interacting with the nuclei of atmospheric components. These products start from the upper layers of the atmosphere and form cosmic radiation exposures at decreasing density towards ground level.

Natural radionuclides of terrestrial origin are present in various concentrations in all surrounding environments, including the human body itself (6 and 1). In addition, people receive radiation doses from industrial or medical applications of artificially produced radioactive substances. An important part of the 
dose from radiation sources defined as artificial radiation sources is due to $X$-rays used for diagnostic purposes and radioactive substances used in nuclear medicine (7-10).

Apart from these, nuclear tests and nuclear reactor accidents caused by radioactive substances spread to the atmosphere, dry sprinkling and rainfall, soil, water and vegetation is infected.

Radioactive substances that accumulate in the receiving environment (soil, water, air) significantly alter local and regional radioactivity. Cosmic sources, radioactive elements in rocks and radically generated radionuclides provide environmental gamma radiation. When the geological structure of the world is examined, it is seen that there are rock beds just below the soil layer of certain thickness. It is known that a significant part of gamma radiation is caused by the surface layer at a depth of $0-25 \mathrm{~cm}$ (11).

Gamma radiation from naturally occurring radioisotopes such as ${ }^{238} \mathrm{U},{ }^{232} \mathrm{Th}$ and ${ }^{40} \mathrm{~K}$ is known as terrestrial background radiation and contributes to the total. The calculations show that $50-80 \%$ of the total gamma dose is due to ${ }^{238} \mathrm{U},{ }^{232} \mathrm{Th}$ and ${ }^{40} \mathrm{~K}$ natural radionuclides on the ground surface (12).

Natural radioactive nuclei are found in high concentration especially in granite, volcanic, phosphate, and salt rocks. Besides, the lowest radioactivity concentration is found in lime rocks. The metamorphic rocks have a concentration of rocks in which they are formed. Table 1 shows the gamma radiation dose rates of radium, uranium, thorium, and potassium in rocks (13).

Table 1. Gamma radiation dose rates caused by radium, uranium, thorium, and potassium in rocks (14).

\begin{tabular}{ccccc}
\hline Rock type & \multicolumn{4}{c}{ Dose Intensity $\left(\mathbf{m S v} \mathbf{~ h}^{-\mathbf{1}}\right)$} \\
\cline { 2 - 5 } & ${ }^{226} \mathrm{Ra}$ & ${ }^{238} \mathrm{U}$ & ${ }^{232} \mathrm{Th}$ & ${ }^{40} \mathrm{~K}$ \\
\hline Volcanic Rocks & 2.4 & 2.6 & 3.7 & 3.5 \\
& & & \\
& \multicolumn{5}{c}{ Sedimentary rocks } \\
Sandstone & 1.3 & 0.7 & 1.8 & 1.5 \\
Stratified & 2.0 & 0.7 & 3.1 & 3.6 \\
Limy & 0.7 & 0.8 & 0.4 & 0.4 \\
\hline
\end{tabular}

Considering the values in Table 1 , the annual effective dose taken from natural radiation sources exposed to living organisms worldwide is $2.4 \mathrm{mSv}$. The dose from a lung film is 0.02 mSv. Lung examination with computed tomography is $8 \mathrm{mSv}$. due to Chernobyl Accident, the average dose of Turkish people is $0.5 \mathrm{mSv}$ (15).

Several studies have been conducted in the previous years regarding the determination of gamma dose and effective dose rates (16-22).

In this study, Gamma dose rates were measured at 25 different points around a $60 \mathrm{~km}$ area in Güre, Küçükkuyu and Kazdağı regions. This study gave important results in terms of determining the gamma dose values for the region.

\section{MATERIAL AND METHODS}

The study area lies between the Behramkale district of the Gulf of Edremit and the Zeytinli village in the province of Balıkesir and Çanakkale (Figure 1). There are many fault zones and thermal water resources in the region. The gamma dose rate absorbed in the air, consists of the sum of cosmic and terrestrial radiations. Measurements were taken with a gamma radiation measuring device at a height of 1 meter from the soil surface to determine background levels of the district. The gamma dose velocity values (ADRA) absorbed in the air are composed of terrestrial and cosmic radiation values. The difference between the values of terrestrial radiation due to the concentration of radionuclides in the soil and the total radiation value is equal to the gamma dose rate components of cosmic radiation. The samples were collected at an interval of approximately $2.5 \mathrm{~km}$ from an area of 60 kilometer square between Behramkale and Zeytinli Village. Twenty-five measurements were taken from the study area. The sample coordinates of the study 
area are given in Table 2. Portable Eberline Smart Portable (ESP) scintillator device is used in measurements. The absorbed gamma doses obtained in $\mathrm{nGy} / \mathrm{h}$ were converted into the annual effective dose in mSv / y using $0.7 \mathrm{~Sv} /$ Gy conversion factor and 0.8 for the closed area and 0.2 for the open area.

As the measurements were made for the open area, the factor of 0.2 was used in the calculations. The annual effective dose was calculated using the following equation $(23,6)$. The formula used in the calculation is given below.

$$
\begin{aligned}
\text { AEDE }= & \text { ADRA } \times \text { DCF } \times \text { OF } \times \mathrm{T} \\
E_{H}(\mathrm{mSV} / \mathrm{y})= & \mathrm{D}_{H}(\mathrm{nG} / \mathrm{h}) \times 365.25 \times 24 \times 0.7 \\
& \mathrm{~Sv} / \mathrm{G} y \times 10^{-6} \times 0.2
\end{aligned}
$$

The terrestrial and cosmic radiation risk values (ELCR) of the people living in the area were calculated by the following equation (24).

$$
E L C R=A E D E \times D L \times R F
$$

Here, the annual exposure value in the AEDE mSv / y unit, DL average life span (70 years), RF refers to the risk factor $\left(0.055 \mathrm{~Sv}^{-1}\right)$ recommended by International Commission on Radiological Protection-103 (ICRP 103) (25).

Geological characteristics of the study area The main units in the study area begin with unallocated gneisses, metagranites, schists, amphibolites and marbles from the Cambrian or Precambrian age. To the top, Precambrian amphibolites, Paleozoic and Permian marbles and metabasic rocks form the basic units. These basement units represent the Mesozoic rocks of the Upper Cretaceous ophiolitic melange. Mesozoic is unconformably overlain by Miocene granitoids, Middle Miocene unspoiled volcanics, andesite, dacite, rhyolite, rhyodacite type volcanic rocks. The upper Miocene pyroclastic rocks, Upper Miocene terrestrial crumbs and neritic limestones are found on these units. All these old rocks are locally overlain by Quaternary slope and alluviums (Figure 1).

The stratigraphic descriptions and regional distributions of the geocronologically defined units are as follows. In the Küçükkuyu section of the study area there are geologically Arıklı ignebrite, Küçükkuyu Formation and Hallaçlar Volcanites. In Güre region, there are mainly Pliocene Bayramiç Formation, Hallaçlar Volcanite, Oligocene-Miocene Granitoids and Çetmi Melange (26).
In the Oligo-Miocene period, a thick sedimentary deposit was developed at the southern foothills of Kazdağı. Starting with the red terrestrial sediments, this sequence passes to the upper lacustrine flysch sequence. In the upper levels of the sequence, the white colored tuff is clearly identified on the southern and western skirts of Kazdağı and its continuity is observed. This explosive volcanism, which is also a predictor of the early Miocene active volcanism, has more common older units, a common lava and prioclastic equivalent, and covered the area like a carpet. In the region, the representative products of this volcanic community such as lava, dyke and vein are widely seen. The Behramkale Village flow structures are located on a beautiful lava flow (27).

The youngest unit recognized in the Kazdağları is a sedimentary group of Upper Miocene Pliocene age and consisting mainly of lacustrine marls and limestones. This unit, which can be easily recognized and distinguished in the field with its white color, was deposited after the development of the anticline formed in Kazdağı. While rising to the present position of the Kaz Mountains, these rocks also were risen on the shoulder of the mountain (27).

\section{RESULTS}

Gamma dose values of the study area and calculated annual effective dose values are given in Table 2. The measurement locations are given in Figure 1 and Table 2, and it is clearly seen in Table 2 that the measurement results differ according to the basement rocks. The gamma dose values of undifferentiated massive volcanics and undifferentiated andesitic volcanics were found to be between 117 (nGy / h) and 243 (nGy / h). The gamma dose values of andesitic pyroclastic rocks were found to be between 65.4 (nGy / h) and 79.0 (nGy / h). In the measurements made in the ophiolitic rocks, the gamma dose values are 238 ( $\mathrm{nGy} / \mathrm{h}$ ). In the metamorphic rocks, slope debris and alluvium areas, the gamma dose values are between 43.8 (nGy / h) and 85.6 (nGy / h). It was observed that the measured values were high especially in the areas with massive unstabilized volcanic rocks and massive metamorphic rocks. 


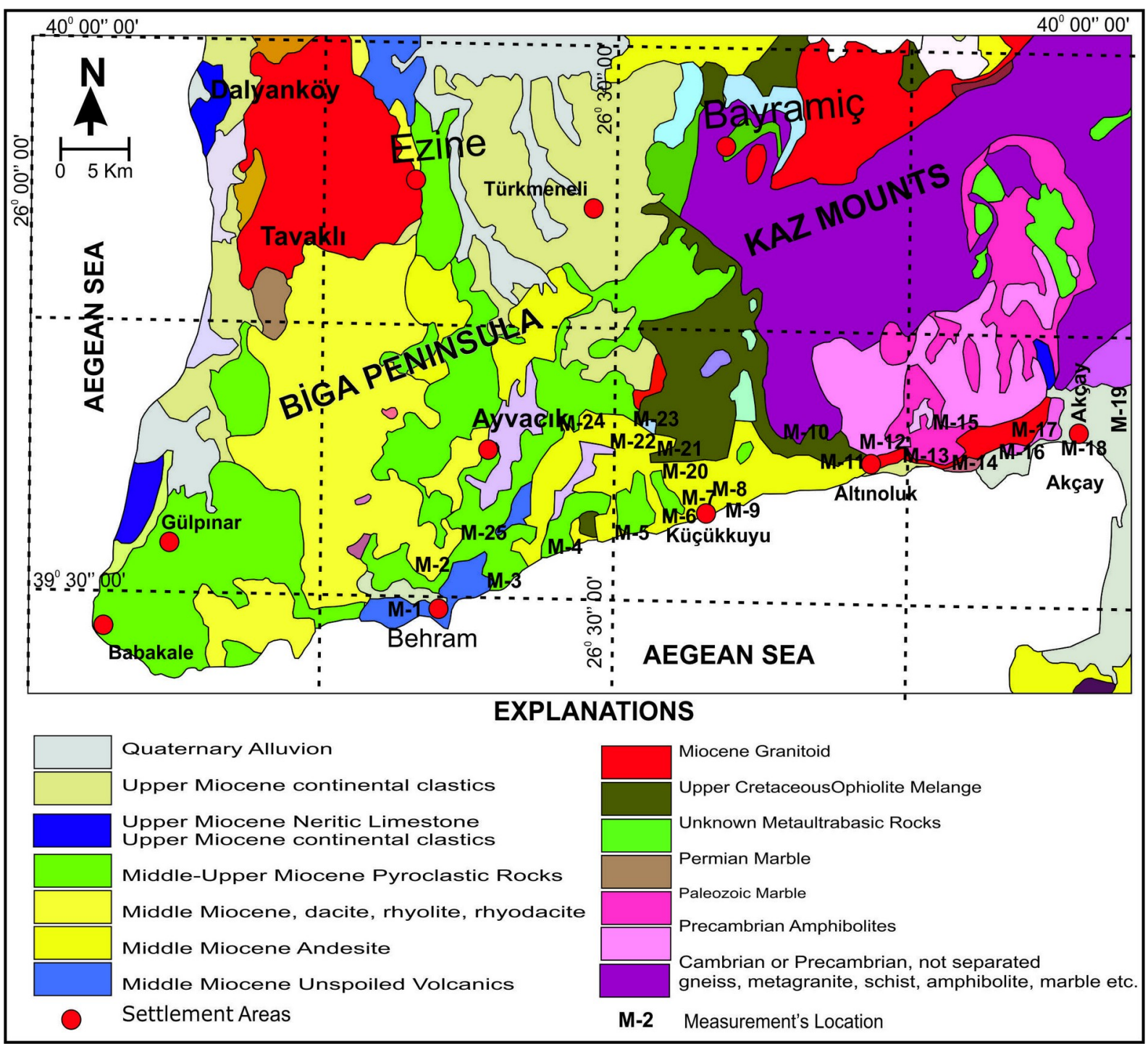

Figure 1. Geological Map of the Biga Peninsula (28) 
Table 2. Gamma dose and annual effective dose rates obtained from the study area.

\begin{tabular}{|c|c|c|c|c|c|}
\hline \multirow{2}{*}{$\begin{array}{l}\text { GEOLOGICAL UNIT } \\
\text { DEFINITIONS } \\
\text { Unspoiled Volcanic } \\
\text { Rocks }\end{array}$} & \multicolumn{2}{|c|}{$\begin{array}{l}\text { GEOGRAPHIC } \\
\text { COORDINATES }\end{array}$} & \multirow{2}{*}{$\begin{array}{l}\text { GAMMA } \\
\text { DOSE } \\
\text { RATE } \\
\text { (ADRA) } \\
\text { (nGy/y) } \\
134\end{array}$} & \multirow{2}{*}{\begin{tabular}{l} 
ANNUAL \\
EFFECTIVE \\
DOSE \\
EQUIVALEN \\
T (AEDE) \\
(mSV) \\
\multicolumn{1}{c}{0,16}
\end{tabular}} & \multirow{2}{*}{\begin{tabular}{l} 
CANCER \\
RISK \\
VALUES \\
(ELCR) [E- \\
4] \\
\multicolumn{1}{c}{6,16}
\end{tabular}} \\
\hline & 0442927 & 4371703 & & & \\
\hline \multirow{2}{*}{ Andesitic Volcanites } & 0445878 & 4371896 & 243 & 0,3 & 12 \\
\hline & 0449392 & 4373146 & 143 & 0,18 & 6,93 \\
\hline \multirow{2}{*}{$\begin{array}{l}\text { Andesitic Pyroclastic } \\
\text { Rocks }\end{array}$} & 0452207 & 4374415 & 65,4 & 0,08 & 3,08 \\
\hline & 0456961 & 4375580 & 77,5 & 0,095 & 3,7 \\
\hline Andesitic Volcanites & 0462376 & 4376462 & 148 & 0,18 & 6,93 \\
\hline $\begin{array}{l}\text { Alluvium of Andesitic } \\
\text { Components }\end{array}$ & 0464541 & 4377369 & 80,8 & 0,1 & 3,85 \\
\hline Andesitic Volcanites & 0464852 & 4377464 & 236 & 0,3 & 12 \\
\hline \multirow{3}{*}{$\begin{array}{l}\text { Alluvium of Andesitic } \\
\text { Components }\end{array}$} & 0572859 & 4556510 & 45,2 & 0,06 & 2,31 \\
\hline & 0474996 & 4379777 & 75,6 & 0,09 & 3,5 \\
\hline & 0477218 & 4379930 & 82,5 & 0,1 & 3,85 \\
\hline \multirow{2}{*}{$\begin{array}{l}\text { Precambrian } \\
\text { Amphibolites } \\
\end{array}$} & 0477192 & 4380513 & 106 & 0,13 & 5 \\
\hline & 0481992 & 4380036 & 115 & 0,14 & 5,4 \\
\hline \multirow{6}{*}{$\begin{array}{l}\text { Separated } \\
\text { Metamorphic Rocks, } \\
\text { Slope Debris and } \\
\text { Alluvium }\end{array}$} & 0483329 & 4380043 & 73,8 & 0,09 & 3,5 \\
\hline & 0483443 & 4382665 & 43,8 & 0,054 & 2,1 \\
\hline & 0488830 & 4381631 & 84,9 & 0,108 & 4,2 \\
\hline & 0489468 & 4382094 & 85,6 & 0,19 & 7,3 \\
\hline & 0493609 & 4382077 & 71,1 & 0,088 & 3,4 \\
\hline & 0495860 & 4383050 & 61,8 & 0,076 & 2,9 \\
\hline Andesitic Volcanites & 0463639 & 4378276 & 117 & 0,14 & 5,3 \\
\hline $\begin{array}{l}\text { Ophiolitic Melange } \\
\text { Rocks }\end{array}$ & 0462270 & 4378696 & 238 & 0,29 & 11 \\
\hline \multirow{3}{*}{$\begin{array}{l}\text { Andesitic Pyroclastic } \\
\text { Rocks }\end{array}$} & 0460286 & 4381191 & 71,8 & 0,088 & 3,4 \\
\hline & 0458926 & 4382298 & 79,0 & 0,097 & 3,7 \\
\hline & 0453822 & 4382974 & 86,3 & 0,105 & 4 \\
\hline Andesitic Volcanites & 0447112 & 4373791 & 215 & 0,26 & 10 \\
\hline AVERAGE VALUE & & & 111,2 & 0,14 & 5,4 \\
\hline
\end{tabular}

Annual effective dose values were calculated by using gamma dose values. According to the results, the highest effective dose was calculated as $0.3 \mathrm{mSv}$ (Asos Kadırga Bay) at location 2. The lowest effective dose value was calculated at the 15th location: $0.054 \mathrm{mSV}$ (Küçükkuyu Outlet) and the average effective dose value: $0.14 \mathrm{mSv}$ was calculated. For the study area, when the lifetime risk of cancer was calculated by using gamma effective dose values, it was found in the highest number 2 location (0.0012) and the lowest in 15 $(0.00021)$.

\section{CONCLUSION}

According to the results of the analysis, the environmental gamma radiation dose velocity varies between locations. This change is directly related to the concentrations of radioisotopes in the soil structure of the region because the main sources of dose values are land and space origin (11).

The geological formation of each location in the study area was determined lithologically and the gamma dose values were measured and evaluated in detail. According to the results, the 
highest effective dose was calculated as 0.3 mSv at the location 2 (Asos Kadırga Bay). The lowest effective dose value was calculated as $0.054 \mathrm{mSV}$ at the 15th location (Avcllar Village Mountain slope) and $0.14 \mathrm{mSv}$ at the average annual gamma dose. These values are smaller than those of TAEK 2009 (Average Annual Effective Dose: $0.48 \mathrm{mSv}$ ). For the study area, when the lifetime risk of cancer was calculated by using gamma effective dose values, it was found in the highest number 2 location (0.0012) and the lowest in 15 (0.00021). If these calculated values compared with Turkey's average lifetime cancer risk value (0.000239) (29), except ninth and fifteenth locations, all locations' values are higher than Turkey average lifetime risk values of cancer.

\section{REFERENCES}

1. Kapdan, E, Varinlioglu A ve Karahan G. Outdoor Radioactivity and Health Risks in Balıkesir, Northwestern Turkey. Radiation Protection Dosimetry. 2011a, (3) 148: 301309p.

2. Aközcan S. Annual effective dose of naturally occurring radionuclides in soil and sediment, Toxicological and Environmental Chemistry. 2014, 96(3): 379-386p.

3. Akkurt İ, Uyanik NA, Günoğlu K. Radiation Dose Estimation: An In Vitro Measurement For Isparta-Turkey. Ijcesen 2015, 1 (1): 1-4p.

4. Çetin B, Öner F and Akkurt I. Determination of Natural Radioactivity and Associated Radiological Hazard in Excavation Field in Turkey (Oluz Höyük), Acta Physica Polonıca. 2016, 130 (1): 475-478p.

5. Günay $\mathrm{O}$, Aközcan $\mathrm{S}$ And Kulalı $\mathrm{F}$. Determination of Indoor Radon Concentrations. European Journal of Science and Technology. 2018, 13 : 91-97p.

6. UNSCEAR. Report of the United Nations Scientific Committee on the Effects of Atomic Radiation, Sources, Effects, and Risks of Ionizing Radiation. United Nations sales publication, New York. United Nations. 2000. 659p.

7. Kara U, Kaya A, Tekin HO, Akkurt I. Adult Patient Radiation Doses with Multislice Computed Tomography Exam: MSCT Standard Protocols. Acta Physica Polonica. 2017, 3 (132): 1126-1127p.

8. Demir N, Kıvrak A, Üstün $M$, Cesur $A$, Boztosun I. Experimental Study for the Energy
Levels of Europium by the Clinic LINAC. IJCESEN. 2017, 3(1): 47-49p.

9. Karahan G, Bayulken A. Assessment of gamma dose rates around Istanbul (Turkey). J. Environ. Radioact. 2000, 47: 213-221p.

10. Kapdan E, Varinlioglu A ve Karahan G. Radioactivity Levels and Health Risks due to Radionuclides in the Soil of Yalova, Northwestern Turkey. International Journal of Environmental Research. 2011b, 5(4): 837$846 p$.

11. Kam E. Environmental Natural Radioactivity Concentrations of Tekirdag. Yildiz Technical University. Graduate School of Natural and Applied Sciences. Department of Physics, Master Thesis. 2004. 124p. İstanbul.

12. Karayiğit AI, Akgün F, Gayer RA, Temel A. Quality, Palynology, and Palaeoenvironmental Interpretation of the Ilgın Lignite, Turkey, International Journal of Coal Geology. 1999, (38): 219-236p.

13. NCRP. Report 45, National Council on Radiation Protection and Measurements No.45, Natural Bacround Radiation in the U.S., Soil Radiactivity. 1975, 270p.

14. NCRP. National Council on Radiation Protection and Measurements. Enviromental Radiation Measurement, NCRP Report No.50. 1977, 150p.

15. Keçeci M. Radiation and radioactivity http:// mehmetkececi.com/blog/2012/04/08/radiationand-radioactivity/. 2007.

16. Kam E, Yümün ZÜ, Önce $M$, Açıkgöz G. Gamma Dose Rate Values In The Kulakçayırı Natural Lake And The Vicinity (Arnavutköy, İstanbul). Journal of Engineering Technology and Applied Sciences. 2016, 1(1): 29-33p.

17. Kam E, Bozkurt A. Environmental radioactivity measurements in Kastamonu region of northern Turkey. Applied Radiation and Isotopes. 2007, 4 (65): 440-444p.

18. Bozkurt A, Yorulmaz N, Kam E, Karahan G, Osmanlıoğlu AE. Assessment of Enviromental Radioactivity for Şanlıurfa Region of Southeastern Turkey. Radiation Measurements. 2007, 8(42): 1387-1391p.

19. Osmanlıoğlu AE, Kam E, Bozkurt A. Assessment of Enviromental Radioactivity Level for Gaziantep Region of Southeastern Turkey. 
Radiation Protection Dosimetry. 2007, 124 (4): 407-410p.

20. Otansev P, Karahan G, Kam E, Barut İ, Taşkın H. Assessment of Enviromental Radioactivity Concentrations and Gamma Dose Rate Levels in Kayseri, Turkey. Radiation Protection Dosimetry. 2012, 148 (2): 227-236p.

21. Yümün ZÜ, Bayrak K, Aksoy $H$, Ayseli U. A Study of Background Radioactivity Level for Edirne, Turkey. Journal of Engineering Technology and Applied Sciences. 2018, 3(2): 135-139p.

22. Turgay ME. Cancer Risk Determination for IDA villages by using Annual Gamma Doses in Air, around Edremit\&Ayvacık District; Balıkesir\&Çanakkale, Turkey. European Journal of Science and Technology. 2019, 15: 433439p.

23. Kurnaz A. and Turfan N. The Effects of Different Storage Conditions on the Radiometric and Element Content of the Taşköprü Garlic (Allium sativum L.). Turkish Journal of Agriculture - Food Science and Technology. 2017, 5 (4): 373-379p.

24. UNSCEAR. Report of the United Nations Scientific Committee on the Effects of Atomic
Radiation, Sources, Effects, and Risks of Ionizing Radiation. United Nations sales publication. 2008. New York. United Nations. $683 p$.

25. ICRP. ICRP Publication 103 Recommendations of the ICRP: Annals of the ICRP Volume 37/2-4, Pergamon Press. International Commission on Radiological Protection. 2007. 35p

26. Bingol E, Akyurek B, Korkmazer B. Geology of Biga Peninsula and some properties of Karakaya Formation. 50th Anniversary of the Republic Congress of Earth Sciences, MTA Ens. Ankara. 1973, 70-77p.

27. Yilmaz Y. Geology and Seismicity of Biga Peninsula. National Workshop of Kazdagları Abstract.23 June 2012.Güre, Edremit, Balıkesir. 19-32p.

28. Şenel M. 1/500000 Scale Geological Map of Turkey (İzmir), the General Directorate of Mineral Research and Exploration. 2002. Ankara.

29. Günay O. Determination of Natural Radioactivity and Radiological Effects in some Soil Samples in Beykoz-İstanbul. European Journal of Science and Technology. 2018. No. 12. 
Yümün Z, Kam E, Önce M. JOTCSA. 2020, 7(1): 207-214.

RESEARCH ARTICLE 